DOI: $\underline{\text { https://doi.org/10.31933/jemsi.v2i4 }}$

Received: 2 Januari 2021, Revised: 15 Februari 2021, Publish: 11 Maret 2021

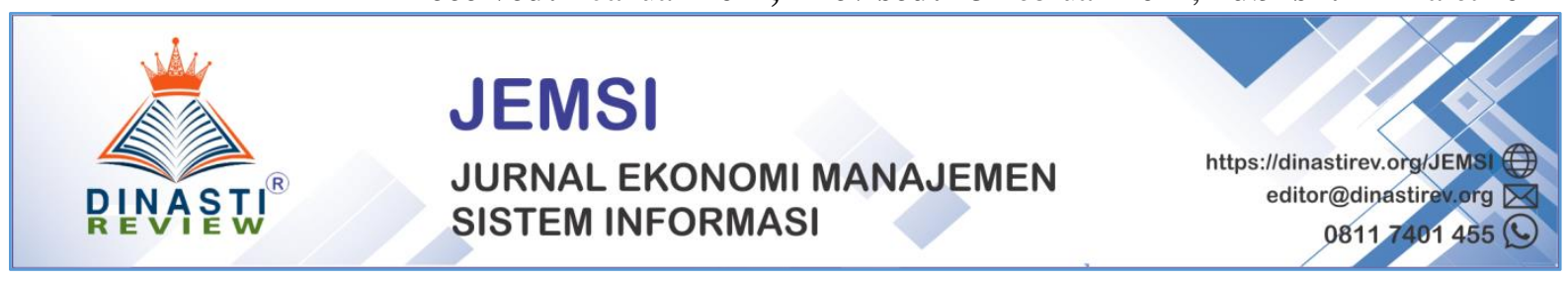

\title{
GAMBARAN PENGETAHUAN AKSEPTOR KB IMPLANT TENTANG EFEK SAMPING ALAT KONTRASEPSI IMPAN DI PUSKESMAS TALANG BAKUNG, KOTA JAMBI TAHUN 2021
}

\author{
Wirda Wirda ${ }^{1}$ \\ 1) Bapelkes Provinsi Jambi, Provinsi Jambi, Indonesia, wirdaedi9@gmail.com
}

\section{Corresponding Author: Wirda Wirda ${ }^{1}$}

Abstrak: Secara kuantitas, jumlah penduduk Indonesia cukup besar, namun secara kualitas melalui Human Development Index (HDI) kondisi Indonesia sangat memprihatinkan. Kondisi ini terjadi karena dari 117 negara Indonesia berada pada posisi 108. Laju pertumbuhan yang tinggi tidak diimbangi oleh peningkatan kualitas penduduk. Berbagai upaya terus dilakukan untuk mengatasinya, yaitu melalui program keluarga berencana. Tujuan dari penelitian ini adalah untuk mendeskripsikan pengetahuan akseptor implan KB tentang efek samping implan kontrasepsi di Puskesmas Talang Bakung Kota Jambi Tahun 2021. Penelitian ini bersifat deskriptif kuantitatif dengan pendekatan cross sectional. Pengambilan sampel dilakukan dengan teknik random sampling sebanyak 37 akseptor. Analisis yang digunakan adalah analisis univariat. Pengumpulan data menggunakan data primer dilakukan dengan mengisi kuesioner yang dibagikan kepada responden. Penelitian ini dilakukan pada bulan 5 Januari - 5 Februari 2021. Hasil penelitian menunjukkan bahwa sebagian besar responden $(67,6 \%)$ memiliki pengetahuan rendah dan seluruh $(100,0 \%)$ responden pernah mengalami efek samping penggunaan kontrasepsi implan. Perlu upaya dan peran petugas kesehatan serta BKKBN untuk lebih meningkatkan sosialisasi alat kontrasepsi. Sosialisasi tersebut mencakup kelebihan maupun kekurangan dari alat kontrasepsi yang dapat menimbulkan efek samping bagi penggunanya. Pengetahuan lebih awal dapat mengurangi efek samping yang mengkhawatirkan dan mengurangi niat akseptor untuk berhenti menggunakan kontrasepsi untuk mencegah kehamilan.

Kata Kunci: Pengetahuan, efek samping alat kontrasepsi implan

\section{PENDAHULUAN}

Pada saat ini penduduk Indonesia berjumlah lebih kurang 230 juta jiwa, dengan pertumbuhan penduduk 1,49 \% pertahun (BKKBN, 2012). Dari segi kuantitas jumlah penduduk Indonesia cukup besar namun dari sisi kualitas melalui Indeks Pembangunan Manusia (IPM) kondisi Indonesia sangat memprihatinkan karena dari 117 negara, Indonesia berada diposisi 108. Tingginya laju pertumbuhan yang tidak diiringi peningkatan kualitas penduduk ini terus dilakukan upaya penanganan yaitu dengan program keluarga berencana. 
Menurut WHO (expert committe, 1970), Keluarga berencana adalah tindakan yang membantu individu/pasangan suami istri untuk medapatkan objektif-objektif tertentu, menghindari kelahiran yang tidak diinginkan, mengatur interval diantara kehamilan dan menentukan jumlah anak dalam keluarga (Anggraini dan Martini, 2012). Tujuan program KB secara filosofis adalah meningkatkan kesejahteraan ibu dan anak serta mewujudkan keluarga kecil yang bahagia dan sejahtera melalui pengendalian kelahiran dan pengendalian pertumbuhan penduduk Indonesia, terciptanya penduduk yang berkualitas, sumber daya yang bermutu dan meningkatkan kesejahteraan keluarga (Handayani, 2010). Berbagai metode dalam pemilihan alat kontrasepsi, salah satu diantaranya adalah implant. Implant adalah suatu alat kontrasepsi yang mengandung levonorgestrel yang dibungkus dalam kapsul silastic-silicone dan diletakan dibawah kulit, Levonorgestrel adalah progestin yang juga dipakai dalam pil KB seperti mini pil atau pil kombinasi ataupun pada AKDR yang bioaktif (Sarwono, 2009).Jenis implant ada 3 macam yaitu implant yang terdiri dari satu kapsul, dua kapsul, dan implant enam kapsul (Saifuddin, 2010).

Data yang diperoleh dari BKKBN Provinsi Jambi pada Tahun 2020 jumlah peserta KB Aktif Provinsi Jambi yaitu 75,43 \% dari jumlah pasangan usia subur . Rincian jumlah akseptor berdasarkan jenis alat kontrasepsi yaitu KB suntik (51,59\%), pil ( 22,15\%), implant (1,05\%), IUD $(0,72 \%),(0,43 \%)$, MOP $(0,03 \%)(B K K B N, 2020)$. Berdasarkan data yang didapatkan dari Dinas Kesehatan Kota Jambi tahun 2020 Jumlah Peserta KB aktif berdasarkan jenis kontrasepsi yaitu Suntik (21\%), Pil (14\%), Kondom (0,27\%), MOP (0,030\%), MOW (0,83\%), Implant (0,334\%), IUD (0,412\%). Berdasarkan hasil laporan dari Dinas Kesehatan Kota Jambi Tahun 2019-2020 terjadi penurunan jumlah akseptor Implan yaitu sebesar 12,14 \%, peserta KB Implant tertinggi terdapat di Puskesmas Talang Bakung, dengan jumlah kunjungan rata - rata setahun sebanyak 54 akseptor aktif.

Implant merupakan Metode Kontrasepsi Jangka Panjang (MKJP) yang berupa susuk yang terbuat dari jenis karet plastik yang berisi hormon, dipasang pada lengan atas. Implan dapat digunakan untuk jangka panjang 3-5 tahun dan bersifat reversibel. Keuntungan dari kontrasepsi implan adalah efektifitasnya tinggi sebesar 99\% untuk mencegah kehamilan selama 3 tahun (angka kegagalan implant, 1 per 100 wanita pertahun dalam 3 tahun pertama), hal ini sama dengan efektifitas AKDR, namun implan memiliki presentase kegagalan yang lebih kecil yaitu sebesar 0,05\%, sedangkan AKDR memiliki presentase kegagalan sebesar 0,8\%. (Kemenkes RI, 2013). Implan merupakan pilihan kontrasepsi yang efektif, aman, dan nyaman bagi wanita. Implan sekali terpasang tidak perlu mengingat setiap hari. Implan berisi levonorgestrel yang merupakan hormon progesterone (Handayani, S, 2010).

Memperhatikan begitu pentingnya Pengetahuan, tentang efek samping alat kontrasepsi implant bagi akseptor KB Implant, maka sebagai salah satu upaya yang dapat dilakukan untuk meningkatan pengetahuan akseptor KB implant adalah dengan memberikan pengetahuan tentang efek samping melalui berbagai metoda misalnya melalui media cetak, elektronik, Pendidikan kesehatan, konseling KB, Sehingga akseptor KB Implan dapat meningkatkan pengetahuan nya tentang efek samping pemakaian KB Implant. Adapun yang menjadi tujuan utama dari penulisan jurnal ini adalah untuk Mengetahui gambaran pengetahuan Akseptor KB Implant tentang efek samping Alat Kontrasepsi Implant. 


\section{KAJIAN PUSTAKA}

Indonesia menghadapi masalah dengan jumlah dan kualitas sumber daya manusia. Untuk dapat mengangkat derajat kehidupan bangsa, perlu digalakkan Keluarga Berencana.Menurut WHO (expert committe, 1970), Keluarga berencana adalah tindakan yang membantu individu/pasangan suami istri untuk medapatkan objektif-objektif tertentu, menghindari kelahiran yang tidak diinginkan, mengatur interval diantara kehamilan dan menentukan jumlah anak dalam keluarga (Anggraini dan Martini, 2012).

Data yang diperoleh dari BKKBN Provinsi Jambi pada Tahun 2020 jumlah peserta KB Aktif Provinsi Jambi yaitu 75,43 \% dari jumlah pasangan usia subur . Rincian jumlah akseptor berdasarkan jenis alat kontrasepsi yaitu KB suntik (51,59\%), pil ( 22,15\%), implant (1,05\%), IUD $(0,72 \%),(0,43 \%)$, MOP $(0,03 \%)(B K K B N, 2020)$. Berdasarkan data yang didapatkan dari Dinas Kesehatan Kota Jambi tahun 2020 Jumlah Peserta KB aktif berdasarkan jenis kontrasepsi yaitu Suntik (21\%), Pil (14\%), Kondom (0,27\%), MOP (0,030\%), MOW (0,83\%), Implant (0,334\%), IUD (0,412\%). Berdasarkan hasil laporan dari Dinas Kesehatan Kota Jambi Tahun 2019-2020 terjadi penurunan jumlah akseptor Implan yaitu sebesar 12,14 \%, peserta KB Implant tertinggi terdapat di Puskesmas Talang Bakung, Tahun 2020, 54 akseptor aktif.

Hasil penelitian menunjukkan bahwa sebagian besar responden $(67,6 \%)$ memiliki pengetahuan rendah dan seluruh $(100,0 \%)$ responden pernah mengalami efek samping penggunaan kontrasepsi implant.Berdasarkan teori Mubarak (2011) mengatakan bahwa pendidikan mempengaruhi pengetahuan, namun tidak sama halnya dalam penelitian ini. Sebagian besar responden memiliki tingkat pendidikan tinggi yaitu SMA/sederajat, sedangkan pengetahuannya rendah. Ini dikarenakan terdapat faktor - faktor lain yang mempengaruhi pengetahuan akseptor KB impant.

Kurangnya pengetahuan tentang efek samping KB implant ini bisa disebabkan kurangnya peran dari tenaga kesehatan, karena pengetahuan dipengaruhi oleh informasi dan informasi yang baik ini adalah dari tenaga kesehatan itu sendiri, sedangan temuan dalam penelitian ini menunjukkan bahwa kebanyakan responden mendapatkan informasi tersebut bukan dari tenaga kesehatan, melainkan dari tetangga atau orang tua yang pernah menggunakannya sehingga tidak ada klarifikasi tentang kebenaran dari pengalaman tentang efek samping tersebut.

Kebanyakan responden yang menjadi akseptor KB setelah mengikuti program keluarga berencana dan masa pakai metode tersebut habis, tidak mau untuk melanjutkan dan memilih berhenti menjadi peserta KB. Hal ini disebabkan beberapa faktor diantaranya pemilihan metode KB tersebut bukan berdasarkan pengetahuan akan pentingnya manfaat, namun banyak disebabkan karena permintaan suami/keluarga, inisiatif sendiri tanpa mengetahui dahulu tentang KB yang dipilih, budaya ikut-ikutan karena masyarakat di tempat tersebut banyak menggunakan metode tertentu yang menjadi pilihannya. Sesuai dengan penelitian Sakinah (2012) yang menyatakan bahwa dari penggunaan kontrasepsi implant masih rendah yaitu 8,94\% dari 615 akseptor, padahal, tingkat pendidikan terbanyak akseptor adalah pada tingkat pendidikan $\geq$ SMA yaitu sebesar 30 orang (38\%). Meskipun pendidikan berpengaruh secara tidak langsung terhadap peningkatan status sosial dan kedudukan seorang wanita, tetapi mereka mempunyai prinsip sendiri untuk membuat keputusan serta menyatakan pendapat misalnya kapan seharusnya hamil, melahirkan dan pemilihan jenis kontrasepsi. 
Hal yang berbeda terjadi pada penelitian Ulfa (2011), yang menyatakan bahwa gambaran pengetahuan akseptor tentang efek samping $\mathrm{KB}$ implant baik, dan tingkat pendidikannya adalah SMA/sederajat. Hal ini bisa terjadi karena banyaknya faktr - faktor yang mempengaruhi pengetahuan.

Berdasarkan uraian diatas, dapat diketahui bahwa sebagian besar pengetahuan akseptor tentang efek samping KB implant masih rendah, sehingga peran tenaga kesehatan untuk sosialisasi tentang efek samping KB implant setelah penggunaannya serta cara penanganannya sehingga kejadian efek samping tersebut tidak menimbulkan kekhawatiran serta kecemasan yang dapat menyebabkan tidak berkelanjutannya penggunaan kontrasepsi. Penjelasan tentang luka bekas insersi KB implant serta lepasnya kapsul KB implant merupakan efek samping KB implant juga perlu dioptimalkan sehingga diharapkan dapat meningkatkan jumlah peserta akseptor KB implant

\section{METODE PENELITIAN}

Penelitian ini merupakan penelitian deskriptif kuantitaif yaitu suatu metode penelitian yang dilakukan dengan tujuan menggambarkan suatu keadaan secara objektif (Notoatmodjo, 2005:138). Metode penelitian ini bertujuan untuk mengetahui gambaran pengetahuan akseptor KB implant tentang efek samping alat kontrasepsi implant di Wilayah Kerja Puskesmas Talang Bakung Kota Jambi Tahun 2021. Penelitian dilakukan pada bulan Januari - februari 2021 di Puskesmas Talang Bakung kota jambi. Penelitian ini menggunakan tekhnik Simple Random Sampling (acak sederhana), dimana setiap populasi berkesempatan untuk menjadi sampel.

Instrument yang digunakan adalah lembar Kuisioner sebanyak 10 pertanyaan dan lembar ceklis yang diisi oleh peneliti. Data yang digunakan adalah data primer yaitu data yang diperoleh secara langsung melalui wawancara dengan menggunakan kuisioner yang telah disediakan peneliti dan lembar ceklis yang diisi oleh peneliti. Sedangkan data sekunder diperoleh dari rekapitulasi jumlah akseptor pengguna KB implant di wilayah kerja Puskesmas Talang Bakung Kota Jambi. Analisis Data yang digunakan adalah analisis Univariate untuk mengetahui distribusi frekuensi responden.

\section{HASIL DAN PEMBAHASAN}

\section{Gambaran Pengetahuan Akseptor KB Implant Tentang Efek Samping Alat Kontrasepsi Implant di Wilayah Kerja Puskesmas Talang Bakung, Kota Jambi Tahun 2021}

Penelitian terhadap pengetahuan akseptor KB implant tentang efek samping alat kontrasepsi implant di Wilayah Kerja Puskesmas Talang Bakung Kota Jambi Tahun 2021, dilihat dari 10 pertanyaan yang terdapat dalam kuesioner meliputi pertanyaan tentang beberapa efek samping dan kekurangan dalam penggunaan KB implant. Jawaban responden dilakukan dengan memberi tanda (X) pada salah satu pilihan jawaban yang dianggap benar pada lembar kuesioner pengetahuan. Dari 10 pertanyaan yang diajukan dan bobot nilai dari masing-masing pertanyaan adalah 1 bila dijawab dengan benar dan 0 bila jawaban salah. Gambaran pengetahuan akseptor KB implant tentang efek samping alat kontrasepsi implant di Wilayah Kerja Puskesmas Talang Bakung Kota Jambi Tahun 2021, dapat dilihat pada Tabel 1. berikut ini: 
Tabel 1. Distribusi frekuensi responden berdasarkan pengetahuan akseptor kb implant tentang efek samping alat kontrasepsi implant di wilayah kerja Puskesmas Talang Bakung, Kota Jambi tahun 2021

\begin{tabular}{|c|c|c|c|c|c|}
\hline \multirow{3}{*}{ No } & \multirow{3}{*}{ Pertanyaan } & \multicolumn{4}{|c|}{ Pengetahuan } \\
\hline & & \multicolumn{2}{|c|}{ Mengetahui } & \multicolumn{2}{|c|}{$\begin{array}{c}\text { Tidak } \\
\text { Mengetahui }\end{array}$} \\
\hline & & $\sum$ & $\%$ & $\sum$ & $\%$ \\
\hline 1 & $\begin{array}{l}\text { Efek samping yang terjadi pada pemakaian KB Implant adalah haid tidak } \\
\text { teratur }\end{array}$ & 37 & 100,0 & 0 & 0,0 \\
\hline 2 & $\begin{array}{l}\text { Efek samping KB implant terhadap berat badan yaitu berat badan } \\
\text { menambah / menurun }\end{array}$ & 14 & 37,8 & 23 & 62,2 \\
\hline 3 & $\begin{array}{l}\text { Jika mengalami perdarahan bercak setelah memakai Kb implant sebaiknya } \\
\text { tetap melanjutkan pemakaian dan konsultasi ke bidan }\end{array}$ & 29 & 78,4 & 8 & 21,6 \\
\hline 4 & Luka bekas tempat memasukan batang implant bisa menyebabkan infeksi & 12 & 32,4 & 25 & 67,6 \\
\hline 5 & $\begin{array}{l}\text { Perubahan siklus haid pada tahun pertama pertama merupakan hal yang } \\
\text { normal karena merupakan pengaruh dari hormon }\end{array}$ & 37 & 100,0 & 0 & 0,0 \\
\hline 6 & $\begin{array}{l}\text { Jika tidak mendapat haid saat memakai Kb implant sebaiknya } \\
\text { memeriksakan diri ke bidan bahwa ibu tidak hamil dan melanjutkan } \\
\text { pemakain }\end{array}$ & 25 & 67,6 & 12 & 32,4 \\
\hline 7 & $\begin{array}{l}\text { Jika ada batang implant yang terlepas dari tempat pemasangannya termasuk } \\
\text { efek samping dari KB Implant }\end{array}$ & 9 & 24,3 & 28 & 75,7 \\
\hline 8 & $\begin{array}{l}\text { Yang menyebabkan ibu mengalami efek samping saat memakai KB implant } \\
\text { adalah hormon yang terdapat pada alat KB tersebut }\end{array}$ & 37 & 100,0 & 0 & 0,0 \\
\hline 9 & Kerugian dari pemakian KB Implant adalah biaya pemasangan yang mahal & 21 & 56,8 & 16 & 43,2 \\
\hline 10 & $\begin{array}{l}\text { Kerugian kontrasepsi Implant yang berhubungan dengan pemasangan } \\
\text { adalah harus dipasang oleh tenaga medis }\end{array}$ & 37 & 100,0 & 0 & 0,0 \\
\hline
\end{tabular}

Berdasarkan Tabel 1. di atas, diperoleh gambaran pengetahuan akseptor tentang efek samping penggunaan KB implant yang banyak dijawab salah yaitu tentang efek samping $\mathrm{KB}$ implant terhadap berat badan yaitu berat badan menambah/menurun sebanyak 14 responden (37,8\%) mengetahui dan 23 responden $(62,2 \%)$ tidak mengetahui. Luka bekas tempat memasukan batang implant bisa menyebabkan infeksi sebanyak 12 responden $(32,4 \%)$ mengetahui dan 25 responden $(67,6 \%)$ tidak mengetahui. Jika ada batang implant yang terlepas dari tempat pemasangannya termasuk efek samping dari KB Implant sebanyak 9 responden $(24,3 \%)$ mengetahui dan 28 responden $(75,7 \%)$ tidak mengetahui.

Dari hasil pengolahan data diperoleh skor total jawaban pengetahuan dengan nilai minimum (5) dan maksimum (10). Pengetahuan akseptor KB implant tentang efek samping alat kontrasepsi implant dalam hal ini dikategorikan menjadi dua yaitu pengetahuan tinggi dan pengetahuan rendah. Cut Off Point pada variabel ini dengan menggunakan nilai $\geq 76 \%(>8$ pertanyaan), jika nilai skor total jawaban $\geq 76 \%$ ( $>8$ pertanyaan) dikategorikan pengetahuan tinggi dan jika nilai skor total jawaban $<76 \%$ ( $<8$ pertanyaan) diketagorikan pengetahuan rendah. Agar gambaran distribusi pengetahuan akseptor KB implant tentang efek samping alat kontrasepsi implant lebih jelas maka dapat dilihat pada Diagram 1. 


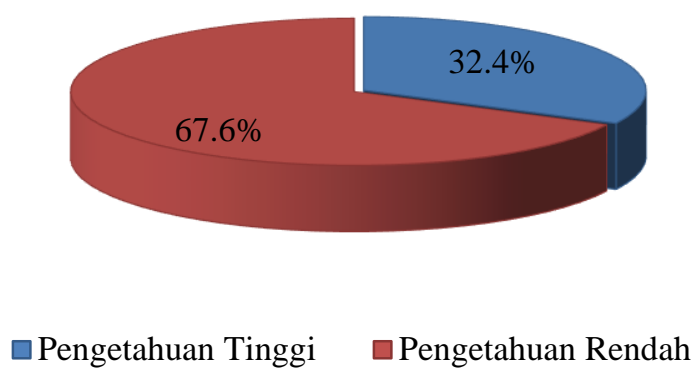

Diagram 1. Distribusi frekuensi responden berdasarkan pengetahuan akseptor KB implant tentang efek samping alat kontrasepsi implant di wilayah kerja Puskesmas Talang Bakung, Kota Jambi tahun 2021

Berdasarkan Diagram 1. di atas, diperoleh gambaran pengetahuan akseptor KB implant tentang efek samping alat kontrasepsi implant di Wilayah Kerja Puskesmas Talang Bakung Kota Jambi Tahun 2021 menunjukkan bahwa sebanyak 12 responden $(32,4 \%)$ memiliki pengetahuan tinggi dan 25 responden $(67,6 \%)$ memiliki pengetahuan rendah.

\section{Gambaran Kejadian Efek Samping Alat Kontrasepsi Implant Pada Akseptor KB Implant di Wilayah Kerja Puskesmas Talang Bakung, Kota Jambi Tahun 2021}

Penelitian terhadap kejadian efek samping alat kontrasepsi implant pada akseptor KB implant di Wilayah Kerja Puskesmas Talang Bakung Kota Jambi Tahun 2021 menggunakan lembar kuesioner berupa check list yang meliputi pernyataan tentang gejala yang dialami setelah menggunakan alat kontrasepsi implant. Jawaban responden dilakukan dengan memberi tanda $(\sqrt{ })$ pada salah satu atau lebih efek samping yang pernah dirasakan oleh akseptor KB implant seperti yang tersedia pada pilihan yang ada pada lembar kuesioner efek samping alat kontrasepsi implant.

Dari 5 pernyataan yang diajukan dan bobot nilai dari masing-masing pertanyaan adalah 1 bila dijawab "pernah" dan 0 bila jawaban "tidak pernah". Gambaran kejadian efek samping alat kontrasepsi implant pada akseptor KB implant di Wilayah Kerja Puskesmas Talang Bakung Kota Jambi Tahun 2021, dapat dilihat pada Tabel 2. berikut ini:

Tabel 2. Distribusi frekuensi responden berdasarkan kejadian efek samping alat kontrasepsi implant pada akseptor KB implant di wilayah kerja Puskesmas Talang Bakung, Kota Jambi tahun 2021

\begin{tabular}{llcccc}
\hline \multirow{2}{*}{ No } & \multirow{2}{*}{ Pertanyaan } & \multicolumn{4}{c}{ Efek Samping } \\
\cline { 3 - 6 } & & \multicolumn{3}{c}{ Pernah } & \multicolumn{3}{c}{ Tidak Pernah } \\
\cline { 3 - 6 } & & $\sum$ & $\%$ & $\sum$ & $\%$ \\
\hline 1 & Amenorhea (tidak mendapat haid) & 18 & 48,6 & 19 & 51,4 \\
\hline 2 & Perdarahan bercak (spooting ringan) & 25 & 67,6 & 12 & 32,4 \\
\hline 3 & Pertambahan atau kehilangan berat badan & 30 & 81,1 & 7 & 18,9 \\
\hline 4 & Ekspulsi (kapsul terlepas dari tempatnya) & 0 & 0,0 & 37 & 100,0 \\
\hline 5 & Infeksi pada daerah insersi (daerah luka) & 0 & 0,0 & 37 & 100,0 \\
\hline
\end{tabular}

Berdasarkan Tabel 2. di atas, diperoleh gambaran kejadian efek samping dari penggunaan $\mathrm{KB}$ implant yang terbanyak yaitu terjadinya pertambahan atau kehilangan berat badan sebanyak 30 responden $(81,1 \%)$ pernah mengalami dan 7 responden $(18,9 \%)$ tidak pernah mengalami. Kejadian efek samping yang banyak terjadi juga pada penggunaan KB implant adalah perdarahan bercak (spooting ringan) sebanyak 25 responden $(67,6 \%)$ pernah 
mengalami dan 12 responden $(32,4 \%)$ tidak pernah mengalami. Kejadian efek samping yang juga masih banyak terjadi yaitu amenorhea (tidak mendapat haid) setelah menggunakan KB implant sebanyak 18 responden $(48,6 \%)$ pernah mengalami dan 19 responden $(51,4 \%)$ tidak pernah mengalami.

Dari hasil pengolahan data diperoleh skor total jawaban kejadian efek samping dengan nilai minimum (1) dan maksimum (3). Kejadian efek samping alat kontrasepsi implant dalam hal ini dikategorikan menjadi dua yaitu pernah mengalami dan tidak pernah mengalami efek samping. Cut Off Point pada variabel ini dengan menggunakan nilai 100\% (> 8 pertanyaan), jika nilai skor total jawaban $>0 \%$ ( $>1$ pernyataan dijawab "ya") dikategorikan pernah mengalami dan jika nilai skor total jawaban $=0 \%$ (tidak satu pun pertanyataan dijawab ya) diketagorikan tidak pernah mengalami. Agar gambaran distribusi kejadian efek samping alat kontrasepsi implant lebih jelas maka dapat dilihat pada Diagram 2. berikut ini:

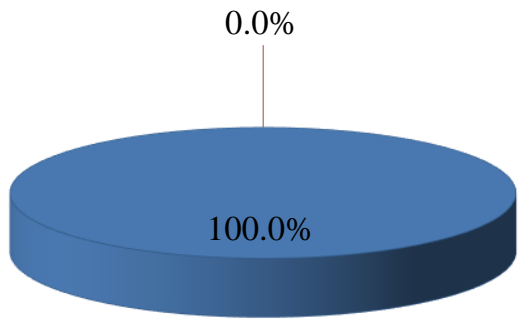

$\square$ Pernah Mengalami $\square$ Tidak Pernah Mengalami

Diagram 2. Distribusi frekuensi responden berdasarkan kejadian efek samping alat kontrasepsi implant pada akseptor KB implant di wilayah kerja Puskesmas Talang Bakung, Kota Jambi tahun 2021

Berdasarkan Diagram 2. di atas, diperoleh gambaran kejadian efek samping alat kontrasepsi implant pada akseptor KB implant di Wilayah Kerja Puskesmas Talang Bakung Kota Jambi Tahun 2021 menunjukkan bahwa seluruhnya yaitu sebanyak 37 responden $(100,0 \%)$ pernah mengalami efek samping.

\section{Pembahasan}

\section{Gambaran Pengetahuan Akseptor KB Implant Tentang Efek Samping Alat Kontrasepsi Implant di Wilayah Kerja Puskesmas Talang Bakung, Kota Jambi Tahun 2021}

Hasil penelitian terhadap gambaran pengetahuan akseptor KB implant tentang efek samping alat kontrasepsi implant di Wilayah Kerja Puskesmas Talang Bakung Kota Jambi Tahun 2021 menunjukkan bahwa dari 37 responden yang diteliti, 25 responden $(67,6 \%)$ memiliki pengetahuan rendah. Pengetahuan seseorang dapat dipengaruhi oleh beberapa faktor, diantaranya pendidikan, pekerjaan, umur, minat, pengalaman, kebudayaan, lingkungan sekitar, dan informasi.

Berdasarkan teori Mubarak (2011) mengatakan bahwa pendidikan mempengaruhi pengetahuan, namun tidak sama halnya dalam penelitian ini. Sebagian besar responden memiliki tingkat pendidikan tinggi yaitu SMA/sederajat, sedangkan pengetahuannya rendah. Ini dikarenakan terdapat faktor - faktor lain yang mempengaruhi pengetahuan akseptor KB implant. Sebagian besar responden masih menjawab salah tentang efek samping KB implant 
terhadap berat badan yaitu tidak hanya menyebabkan pertambahan berat badan, tetapi juga dapat menurunkan berat badan. Kebanyakan para akseptor hanya mengetahui bahwa efek samping yang umum terjadi pada penggunaan alat kontrasepsi akan mengakibatkan pertambahan berat badan saja. Kurangnya pengetahuan tentang efek samping KB implant ini bisa disebabkan kurangnya peran dari tenaga kesehatan, karena pengetahuan dipengaruhi oleh informasi dan informasi yang baik ini adalah dari tenaga kesehatan itu sendiri, sedangan temuan dalam penelitian ini menunjukkan bahwa kebanyakan responden mendapatkan informasi tersebut bukan dari tenaga kesehatan, melainkan dari tetangga atau orang tua yang pernah menggunakannya sehingga tidak ada klarifikasi tentang kebenaran dari pengalaman tentang efek samping tersebut.

Selanjutnya, sebagian akseptor KB implant juga tidak mengetahui bahwa luka bekas insersi KB impant dapat menyebabkan infeksi, dan sebagian responden tidak mengetahui bahwa keluarnya kapsul KB implant dari tempat pemasangan merupakan salah satu efek samping dari KB implant. Kurangnya pengetahuan tentang efek samping ini bisa dikarenakan akseptor KB mempunyai kesbukan masing - masing, sehingga mengurangi minat dari akseptor untuk mengetahui tentang efek samping tersebut. Sesuai dengan teori yang dikemukakan Mubarak (2011) yang mengatakan bahwa minat merupakan suatu kecenderungan atau keinginan yang tinggi terhadap sesuatu yang dapat menyebabkan seseorang mencoba mencoba dan menekun suatu hal, sehingga pengetahuan yang dimilikinya semakin mendalam, yang dalam hal ini adalah minat untuk mengetahui efek samping KB implant. Kebanyakan responden yang menjadi akseptor KB setelah mengikuti program keluarga berencana dan masa pakai metode tersebut habis, tidak mau untuk melanjutkan dan memilih berhenti menjadi peserta KB. Hal ini disebabkan beberapa faktor diantaranya pemilihan metode KB tersebut bukan berdasarkan pengetahuan akan pentingnya manfaat, namun banyak disebabkan karena permintaan suami/keluarga, inisiatif sendiri tanpa mengetahui dahulu tentang KB yang dipilih, budaya ikut-ikutan karena masyarakat di tempat tersebut banyak menggunakan metode tertentu yang menjadi pilihannya.

Sesuai dengan penelitian Sakinah (2012) yang menyatakan bahwa dari penggunaan kontrasepsi implant masih rendah yaitu 8,94\% dari 615 akseptor, padahal, tingkat pendidikan terbanyak akseptor adalah pada tingkat pendidikan $\geq$ SMA yaitu sebesar 30 orang (38\%). Meskipun pendidikan berpengaruh secara tidak langsung terhadap peningkatan status sosial dan kedudukan seorang wanita, tetapi mereka mempunyai prinsip sendiri untuk membuat keputusan serta menyatakan pendapat misalnya kapan seharusnya hamil, melahirkan dan pemilihan jenis kontrasepsi. Hal yang berbeda terjadi pada penelitian Ulfa (2011), yang menyatakan bahwa gambaran pengetahuan akseptor tentang efek samping KB implant baik, dan tingkat pendidikannya adalah SMA/sederajat. Hal ini bisa terjadi karena banyaknya faktorfaktor yang mempengaruhi pengetahuan.

Berdasarkan uraian diatas, dapat diketahui bahwa sebagian besar pengetahuan akseptor tentang efek samping KB implant masih rendah, sehingga peran tenaga kesehatan untuk memberikan pengetahuan tentang efek samping melalui berbagai metoda misalnya melalui media cetak, elektronik, Pendidikan kesehatan, konseling KB, Sehingga akseptor KB Implan dapat meningkatkan pengetahuan nya tentang efek samping pemakaian KB Implant. 


\section{Gambaran Kejadian Efek Samping Alat Kontrasepsi Implant Pada Akseptor KB Implant di Wilayah Kerja Puskesmas Talang Banjar Kota Jambi Tahun 2021}

Hasil penelitian terhadap gambaran kejadian efek samping alat kontrasepsi implant pada akseptor KB implant di Wilayah Kerja Puskesmas Talang Bakung Kota Jambi Tahun 2021 menunjukkan bahwa seluruhnya yaitu sebanyak 37 responden (100,0\%) pernah mengalami efek samping. Hal ini sejalan dengan penelitian Ulfa (2010) yang menunjukkan bahwa sebagian besar responden pernah mengalami efek samping dari KB implant.

Adapun kejadian efek samping dari penggunaan KB implant yang terbanyak yaitu terjadinya pertambahan atau kehilangan berat badan, perdarahan bercak (spooting ringan), amenorhea (tidak mendapat haid) setelah menggunakan KB implant. Sedangkan kejadian efek samping yang jarang terjadi yaitu ekspulsi (lepasnya kapsul dari tempatnya) dan infeksi pada daerah insersi (daerah luka).

Berat badan bertambah atau menurun secara cepat dapat diliat dalam waktu 7 bulan pertama setelah pemasangan implan. Hormon progreston mempermudakan perubahan karbohidrat dan gula menjadi lemak dan merangsang nafsu makan serta menurunkan aktifitas fisik, sehingga adanya implan dapat menyebabkan berat badan bertambah. Penambahan berat badan ini disebabkan karena hormone yang mengandung progesterone dapat merangsang pusat pengendali nafsu makan dihipotalamus yang menyebabkan akseptor makan lebih dari biasanya (Irianto, 2014).

Menurut Prawiroharjo (2007) efek penambahan berat badan dapat disebabkan karena hormon yang terkandung dapat merangsang pusat pengendali nafsu makan dihipotalamus yang menyebabkan akseptor makan lebih banyak dari biasanya. Penelitian lain yang dilakukan oleh Larasati (2017) dengan judul hubungan penggunaan kontrasepsi implan dengan kenaikan berat badan pada wanita usia subur di puskesmas MLAT II kabupaten sleman Yogyakarta diketahui bahwa responden yang mengalami kenaikan berat badan selama penggunaan kontrasepsi implant sebanyak 23 responden $(63,9 \%)$ lebih besar dibandingkan dengan responden yang tidak mengalami kenaikan yaitu sebanyak 13 responden $(36,1 \%)$.

Menurut Irianto (2014) Gangguan siklus haid terjadi karena ketidak seimbangan hormonal sehingga endometrium mengalami histologia dan kadar FSH yang tingi dapat mengakibatkan terjadinya stimulasi ovarium yang berlebihan (hiperstimulasi) sehingga dijumpai kadar estrogen yang sangat tinggi). Sedangkan menurut (Sinaga E, 2017) Polimenorea merupakan kelainan siklus menstruasi yang menyebabkan wanita berkali - kali mengalami menstruasi dalam sebulan, bias dua atau tiga kali atau bahkan lebih. Normalnya, siklus menstruasi berlangsung selama 21-35 hari dengan durasi sekitar 2-8 hari. Wanita yang mengalami polimenorea memiliki siklus menstruasi yang pendek dari 21 hari dengan pola yang teratur dan jumlah perdarahan yang relatife sama atau lebih banyak. Menurut Astuti (2015) yang mengalami siklus menstruasi kurang dari 21 hari terjadi pada waktu 3 bulan pertama.

Penelitin ini juga sejalan dengan oleh penelitian Rahayu.S (2015) yang menyatakan bahwa efek samping penggunaan kontrasepsi implant adalah mengalami siklus haid tidak teratur ( $<20$ hari atau siklus haid $>28$ hari) yaitu sebanyak 15 akseptor $(45,4 \%)$. Hal ini terjadi pada awal pemakaian kontrasepsi implant, salah satu penyebab terjadinya gangguan siklus haid ini adalah karena ketidak seimbangan hormon sehingga endometrium mengalami histologi. 
Berdasarkan uraian diatas, dapat diketahui bahwa sebagian besar akseptor mengalami efek samping, sehingga peran tenaga kesehatan untuk sosialisasi tentang efek samping KB implant setelah penggunaannya serta cara penanganannya sehingga kejadian efek samping tersebut tidak menimbulkan kekhawatiran serta kecemasan yang dapat menyebabkan tidak berkelanjutannya penggunaan kontrasepsi. Penjelasan tentang luka bekas insersi KB implant serta lepasnya kapsul KB implant merupakan efek samping KB implant juga perlu dioptimalkan sehingga diharapkan dapat meningkatkan jumlah peserta akseptor KB implant.

\section{KESIMPULAN DAN SARAN}

Kesimpulan , Berdasarkan hasil dan uraian dalam pembahasan penelitian tentang gambaran pengetahuan akseptor KB implant tentang efek samping alat kontrasepsi implant di Wilayah Kerja Puskesmas Talang Bakung Kota Jambi Tahun 2021, maka dapat ditarik beberapa kesimpulan sebagai berikut:

a. Sebagian besar $(67,6 \%)$ responden memiliki pengetahuan rendah dan seluruh $(100,0 \%)$ responden pernah mengalami efek samping pada penggunaan alat kontrasepsi implant.

b. Sebagian besar $(67,6 \%)$ responden memiliki pengetahuan rendah dan sebagian lainnya $(32,4 \%)$ responden memiliki pengetahuan tinggi.

c. Seluruh $(100,0 \%)$ responden pernah mengalami efek samping pada penggunaan alat kontrasepsi implant.

Saran dalam penelitian ini adalah agar tenaga kesehatan melakukan sosialisasi dan pendidikan kesehatan tentang efek samping KB implant setelah penggunaannya serta cara penanganannya sehingga kejadian efek samping tersebut tidak menimbulkan kekhawatiran serta kecemasan yang dapat menyebabkan tidak berkelanjutannya penggunaan kontrasepsi.

\section{DAFTAR RUJUKAN}

Anggraini, Yetti. (2010). Pelayanan Keluarga Berencana. Rohima prees. Yogyakarta BBKKBN Provinsi Jambi 2020.

Dinas Kesehatan Kota Jambi. Laporan tahunan 2019 - 2020.

Handayani, Sri. (2010). Buku Ajar Pelayanan Keluarga Berencana. Yogyakarta: Pustaka Rihama.

Manuaba, Dkk. (2010). Ilmu Kebidanan, Penyakit Kandungan, dan KB. Jakarta: Penerbit Buku Kedokteran EGC. viii+693 hlm.

Maulana, Heri.D.J. (2009). Promosi Kesehatan. Jakarta: Penerbit EGC.

Mubarak, WI. (2011). Promosi Kesehatan Untuk Kebidanan. Salemba Medika.

Notoatmodjo, Soekidjo. (2011). Kesehatan masyarakat: Ilmu dan seni. Jakarta: Penerbit Rineka Cipta.

Notoatmodjo, Soekidjo. (2010). Metodologi Penelitian. Jakarta: Penerbit Rineka Cipta. Jakarta: $x i x+243 \mathrm{hlm}$.

Notoatmodjo, Soekidjo. (2005). Metodologi Penelitian. Jakarta: Penerbit Rineka Cipta.

Notoatmodjo, Soekidjo. (2003). I Imu Kesehatan Masyarakat. Jakarta: Penerbit Rineka Cipta.

Nursalam dan F Efendi. (2008). Pendidikan dalam keperawatan. Jakarta: Salemba Medika. 
Saifuddin, AB. (2010). Ilmu Kebidanan. Jakarta: PT Bina Pustaka Sarwono Prawirohardjo. Jakarta:xxiv+982 hlm.

. (2010). Buku Panduan Praktis Pelayanan Kontrasepsi. PT Bina Pustaka Sarwono Prawirohardjo. Jakarta: xxviii+296 hlm.

Sulistyaningsih. (2011). Metodologi Penelitian Kebidanan. Jakarta: Penerbit Graha Ilmu.

Sulistyawati, Ari. (2011). Pelayanan Keluarga Berencana. Jakarta: Penerbit Salemba Medika. Suyanto, Salamah. (2008). Riset Kebidanan. Yogyakarta: Mitra Cendikia.

Wiknjosastro, H, Dkk. (2009). Ilmu Kandungan. Jakarta: PT Bina pustaka Sarwono Prawirohardjo. Jakarta:xxxvi+716 hlm. 